\title{
Crime against women with special reference to Rajasthan
}

\author{
Deepak Singh ${ }^{1}$, BL Chaudhary ${ }^{2 *}$ \\ ${ }^{1}$ Associate Professor, ${ }^{2}$ Additional Professor, ${ }^{1,2}$ Dept. of Forensic Medicine and Toxicology, ${ }^{2}$ All India Institute of Medical sciences, \\ Rishikesh, Uttrakhand, ${ }^{1}$ Geetanjali Medical College, Udaipur, Rajasthan, India
}

*Corresponding Author: BL Chaudhary

Email: drblchaudhary@gmail.com

\begin{abstract}
Introduction: Atrocities/violent crimes against women have risen in recent times in the state of Rajasthan. Traditionally Rajasthan is known for peaceful coexistence of females. Is the changing social milieu being responsible for sudden rise of crimes or the social fabric has been rewoven.

Materials and Methods: The statistical analysis of various parameters and available data from NCRB and state government is scrutinized to see changing pattern in occurrence of crime against women.

Discussion: According to State Police Department data, Rajasthan has witnessed a $66.78 \%$ rise in crime against women in first half of this year compared to same last year. Total number of cases between January -July 2019 is 25,420 compared to 15,242 in 2018. In July alone cases of women atrocities are a whopping 4,898 while they were 2614 in July 2018. Heinous crimes like rape has seen a jump from 2,587 to 3,677. Molestation shows a rise from 3,171 to 5,329. Abduction rose from 2,687 to 3,762. Cases of domestic violence jumped from 5,884 to 11,459 . Dowry related deaths from 231 to 273 . Most of the cases were closed as false reporting and approximately 50\% cases were taken to court. Kota and Jodhpur cities are India's top 10 in the crime against women and Jaipur Commissionerate alone shows a rise of $105.74 \%$. Police attribute this to increase in awareness about crime reporting or compensation but fact remains that this is an indicator of sexual disparity in crime and females still being seen as a soft target.

Conclusion: The settings up of special Police cell and special courts exclusively looking into such matters have speed up case trial and decreased pendency. Equally important is to respect and fear of law in minds of criminals. The onus rest upon us and family to teach values to our children.
\end{abstract}

Keywords: Women, Crime, violence, Sex, Law.

\section{Introduction}

Women have been at the forefront of Indian culture and custom and its torchbearer. Life of Indian is said to be incomplete without a woman be it mother, wife or daughter. With strong western influence and the diaspora affecting the upbringing of the new generation, a perceptible change is being observed in the attitude of male's vis a vis female. They are being objectified and pushed in a corner. The women liberalization has thrown away the shackles of yesteryears and a new modern, powerful, educated, independent, working yet traditional and value-oriented women have come to the fore. They know their strengths and weakness. They are aware of their rights and duties. They have extrapolated their energy into productive offshoots. If we do reality check it will be realized that women are far stronger than men, biologically, emotionally, mentally and the new women are now equally stronger financially and politically. Why then such heinous crimes are committed against them. Is this indicator of men facing threat or some unknown fear of losing the turf to a no longer weaker sex. Though it is a global phenomenon it is more perplexed in the Indian context for fear of being outcaste and procrastination by society.

\section{Materials and Methods}

Violence against females domestic or otherwise has an upward graph. In this present study we statistically analyzed various parameters and available data from National Crime Record Bureau (NCRB) and state government of Rajasthan is scrutinized to see the changing pattern in the occurrence of crime against women. The purpose is to assist the aggrieved party with medicolegal aid to get justice.

\section{Observations}

The data for analysis are collected from the different agencies and available data shows that there has been a definite increase in the crime against females of all ages and of all gravity. Crime against women is seen right from before the child is being born to female like female foeticide, infanticide and later molestation, eve-teasing, dowry, domestic violence, indecent and inappropriate behavior, sexual assault, rape, and workplace harassment. This is retrospective analytical study was undertaken and various data are statically analyzed. According to State Police Department data, Rajasthan has witnessed a $66.78 \%$ rise in crime against women in the first half of this year with total number of 25,420 cases of atrocities against women were reported between January -July 2019 which is substantial higher number than year 2018-19 i.e. 15,242 number.

In July 2019 alone cases of women atrocities are a whopping 4,898 while they were 2614 in July 2018. Heinous crimes like rape have seen a jump from 2,587 to 3,677. Molestation shows a rise from 3,171 to 5,329. Abduction rose from 2,687 to 3,762. Cases of domestic violence jumped from 5,884 to 11,459. Dowry related deaths from 231 of previous year to 273 this year. Most of the cases were closed as FR (false report) due to false 
reporting reason may be various including social pressure and fear of defamation or any life threat warnings and approximately $50 \%$ cases all cases were taken to the court of law. Kota and Jodhpur cities are India's top 10 in the crime against women. Jaipur Commissionerate jurisdiction alone shows a rise of $105.74 \%$ cases crime against women. Police attribute this to an increase in awareness about the crime reporting or compensation but the fact remains that this is an indicator of sexual disparity in crime and the females still being seen as a soft target. Just recently the Rajasthan High Court at Jodhpur has sought from district court data on all FIR registered on order of court related to crime against women and POCSO Act- 2012 within their jurisdiction during the last six months. Cases under sections 376 IPC (Rape), 354 IPC (Assault with intent to outrage the modesty of female, 304 IPC (culpable homicide not amounting to murder, 304B IPC (Death due to burn or injury i.e. Dowry death), 306 IPC (Abetment to suicide), $306 \mathrm{~B}$ are to be included in this list of crime against women.

\section{Discussion}

The last couple of decades has seen a tremendous increase in crime against women. This may be due to more women asking for their rights or males thinking it as an encroachment to their bastion. Women's awareness programs and women right group have given them a forum to address their grievances and come out of their closet to register the crime against perpetrators. It is so ironical that the land of Devi's where women are being worshipped as a goddess is the major sufferer and subject to so much abuse and crime. Molestation has become a norm and outrage of modesty a chivalrous act. The society has shown a downward spiral. Rape is a mental and physical wound and the tormentors pounce upon the victims of any age right from infancy to old age, no age is safe. This reflects the grave deterioration in the socio-familial norms. The right to live about the apex court aims in the direction to give equal rights to females and subsequent entitlement. People are also coming out and speaking out and it is no longer a social taboo. Counseling centers have come up. The need of the hour is to educate the people. Recently the Government of Rajasthan has come up with a novel idea of introducing a chapter on "crime against women" in the school curriculum in session 2020-2021 $1^{5}$ with a purpose to educate and spread awareness amongst the school level students so they are sensitized to this aspect of society. Nirbhaya fund meant for such victims is not being properly used.

In this study we specially analyzed particularly Rajasthan state where reported that a $66.78 \%$ rise in crime against women in the first half of this year with total number of 25,420 cases between January -July 2019 which is substantial higher number than the past year 2018-19 i.e. 15,242 number $^{1,6}$

In July 2019 alone cases of women atrocities are a whopping 4,898 while they were 2614 in July 2018. Heinous crimes like rape have seen a jump from 2,587 to 3,677. Molestation shows a rise from 3,171 to 5,329. Abduction rose from 2,687 to 3,762 . $^{6}$ Cases of domestic violence jumped from 5,884 to 11,459 . Dowry related deaths from 231 of previous year to 273 this year.

About 35 per cent of women worldwide have experienced either physical and/or sexual intimate partner violence or sexual violence by a non-partner at some point of time in their lives. However, in some countries these data are higher up to 70 per cent. Evidence shows that these crime against women may cause of depression, having an abortion and acquiring HIV, compared to women who have not. $^{7}$

Study of four countries from the Middle East and North Africa, men who witnessed their fathers using violence against their mothers, and men who experienced some form of violence at home as children, were significantly more likely found with violence in their adult relationships. For instance, in Lebanon the likelihood of perpetrating physical violence was more than three times higher among men who had witnessed their fathers beating their mothers during childhood than those who did not. ${ }^{8}$

Globally, it is reported that of the 87,000 women were intentionally killed in 2017 , more than half $(50,000-58$ per cent) were killed by their partners or by family members. That shows that 137 women across the globe are killed by their own family every day. In the year 2017 about one third $(30,000)$ of the women intentionally killed by their present or past partner. ${ }^{9}$

The global data shows that adult woman about 51 per cent constituent of all human trafficking victims and women and girls combined data account for 71 per cent. In this trade of trafficking girl victims are nearly three out of every four children. Further, data analysis reported that three out of every four trafficked women and girls are trafficked for sexual exploitation purposes. ${ }^{10}$ In global dimension it is estimated prevalence in the 30 countries that about 200 million women and girls alive present day have undergone through female genital mutilation particularly among migrant and refugee. ${ }^{11}$ Worldwide, nearly 15 million girls age between 15 to 19 have experienced forced sexual intercourse or other sexual acts at some point in their life. Out of these, 9 million girls of this age group were victimized within previous year. ${ }^{12}$

In the USA in the year 2015 survey conducted on female undergraduate university students of 27 universities, 23 percent girls reported having experienced sexual assault or sexual misconduct. One in 10 women in the European Union reported experience of cyber-harassment including having received unwanted, offensive sexually explicit emails or SMS messages, or offensive, inappropriate advances on social networking sites. In a study of multiple Middle East and North Africa countries reported that 40 percent women had experienced street-based sexual harassment like sexual comments, stalking etc. ${ }^{13}$

\section{Conclusion}

Society takes the call when the government fails to deliver. It has been noticed that with the implementation of law and order also rest on the people for whom it is meant. Law is for law abiding citizen. Fear of castration in the society and 
shaming has given way to people coming out and speaking about their experiences. The "ME TOO" campaign has given the people the platform and strength to air their grievance. Many cases which never so light of the day had surfaced and very high and mighty have been prosecuted. The law has tooth and now it is biting as well. It has been seen that any revolution be it political or social, it requires people participation and nothing can be accomplished without their involvement. The way we teach the good and bad touch to children we should also inculcate habits of normal decent behavior in life. The onus rest upon us and the family to teach values to our children. It is the male member who is to be taught about how to respect the females and behave in a civilized fashion and not vice versa. The settings up of special Police cell exclusively looking into such matters have speed up the case trial and decreased the pendency. The setting up of special courts and speedy trial has increased the conviction rate. Time bound trial has helped the disposal rate. Equally important is the respect and fear of law in the minds of criminals which can drastically reduce the offence rate. Above all the education and moral teaching coupled with religious discourses instill a fulfilment of life in god fearing people to make our earth a happy and livable place.

Source of funding: None.

Conflict of Interest: None.

\section{References}

1. NCRB Journal October 2018(1).

2. Bachman. 1994 Violence against Women: A National Crime Victimization Survey Report. NCJ-145325, Washington, D.C: Bureau of Justice Statistics, U.S. Department of Justice.

3. National Commission for Women. 2015-2019 Annual Report. 2018.

4. Ministry of Law and Justice 2013. India Code. Criminal Law Amendment Act 2013, February(July2016)

5. Ministry of Women and Child Development. Press Information Bureau. December 18, 2015.

6. Govt. of India. data.gov.in. (online) September 7, $201 \mathrm{https}$; //data.gov.in/catalog/ crime-against-women.

7. Global and regional estimates of violence against women: prevalence and health effects of intimate partner violence and non-partner sexual violence. The World's Women 2015, Trends and Statistics, Chapter 6.

8. Violence against Women, United Nations Department of Economic and Social Affairs, 2015 and UN Women Global Database on Violence against Women.

9. UN Women Understanding Masculinities: Results from the International Men and Gender Equality Survey (IMAGES) Middle East and North Africa 2017.

10. United Nations Office on Drugs and Crime. Global Study on Homicide 2018;10.

11. UNODC (2016). Global Report on Trafficking in Persons 2016;7:28.

12. UNICEF. Female Genital Mutilation/Cutting: A global concern and United Nations 2018.

13. UNICEF. A Familiar Face: Violence in the lives of children and adolescents. 2017;73-82.

How to cite this article: Chaudhary BL, Singh D. Crime against women with special reference to Rajasthan. Int $J$ Forensic Med Toxicol Sci 2019; 4(4):143-5. 